\title{
Zinc Oxide Eugenol-Formocresol Root Canal Treatment Fails to Treat a Deciduous Tooth with Dentoalveolar Abcess
}

\author{
Arifa Pediarahma ${ }^{1}$, Mochamad F. Rizal ${ }^{2}$ \\ ${ }^{1}$ Pediatric Dentistry Residency Program, Faculty of Dentistry, Universitas Indonesia, Jakarta 10430, \\ Indonesia \\ ${ }^{2}$ Department of Pediatric Dentistry, Faculty of Dentistry, Universitas Indonesia, Jakarta 10430, Indonesia \\ Corresponding e-mail to:levi_pedo@yahoo.com
}

\begin{abstract}
ABSRACT
Irreversible pulp infection can lead to dentoalveolar abscess. Root canal treatment in deciduous teeth is indicated in irreversible pulp infection to maintain children's health and deciduous teeth until its exfoliation period. Success rate of endodontic treatment in deciduous teeth can be enhanced by using antimicrobial root canal filling material. Combination of ZOE-formocresol as root canal filling material has a superior antimicrobial property. Unfortunately, based on some research it is also toxic to the tissue. This case report will discuss about failure of root canal treatment in deciduous tooth with dentoalveolar abscess using combination of ZOE-formocresol as obturating material. There are some factors that possibly cause the failure: complexity of deciduous molar anatomy, the choice of root canal filling material, application of root canal filling material that is not adequate, or an extend pathological condition.
\end{abstract}

\begin{abstract}
ABSTRAK
Perawatan saluran akar dengan pasta Zinc Oxide Eugenol-Formokresol tidak berhasil untuk perawatan gigi sulung dengan abses dentoalveolar. Infeksi pulpa irreversible dapat menyebabkan abses pada area dentoalveolar. Perawatan saluran akar gigi sulung diindikasikan pada infeksi pulpa irreversible untuk menjaga kesehatan anak dan mempertahankan gigi sulung sampai periode eksfoliasi normal. Keberhasilan perawatan endodontik dapat ditingkatkan dengan penggunaan bahan pengisi saluran akar yang bersifat antimikroba. Bahan pengisi kombinasi ZOE-formokresol memiliki sifat antimikroba yang superior, namun pada beberapa penelitian bahan ini juga bersifat toksik terhadap jaringan. Pada laporan kasus ini akan dibahas kegagalan perawatan saluran akar dengan bahan pengisi kombinasi ZOE-formokresol pada gigi sulung dengan abses dentoalveolar. Faktor-faktor penyebab kegagalan antara lain kompleksnya anatomi gigi sulung, pemilihan bahan pengisi, peletakan bahan pengisi yang kurang adekuat, atau kondisi patologis yang sudah meluas.
\end{abstract}

Key words: deciduous teeth, dentoalveolar abscess, ZOE-formocresol

\section{PENDAHULUAN}

Infeksi pulpa irreversible dapat menyebabkan abses pada area dentoalveolar. ${ }^{1}$ Abses dentoalveolar adalah suatu area inflamasi terlokalisasi, terbatas, dan purulen yang dimulai dari ligamen periodontal gigi yang mengalami infeksi. Area ini berisi akumulasi pus, bakteri, produk bakteri, sel-sel inflamasi dan jaringan nekrotik yang terbentuk di tulang sekitar apeks gigi. ${ }^{2,3}$ Abses yang terjadi karena kerusakan pada gigi sulung biasanya lebih menyebar dan jaringan sekitarnya lebih tidak dapat membatasi prosesnya. ${ }^{4}$
Perawatan endodontik pada gigi sulung bertujuan menjaga kesehatan anak dan mempertahankan gigi sulung yang pulpanya telah terbuka sampai periode eksfoliasi normal dan gigi permanen erupsi. PSA (perawatan saluran akar) diindikasikan pada infeksi pulpa irreversible. Keberhasilan perawatan endodontik tergantung dari reduksi atau eliminasi bakteri pada saluran akar dan dapat ditingkatkan dengan penggunaan bahan pengisi saluran akar yang bersifat antimikroba. ${ }^{5-7}$ 
Formokresol dikenal sebagai antimikroba yang superior, dan ZOE (zinc oxide eugenol) adalah bahan pengisi yang sudah banyak digunakan serta dapat menjadi carrier bagi formokresol. Tingkat kesuksesan kombinasi ZOE-formokresol dalam perawatan saluran akar dilaporkan dari beberapa penelitian berkisar antara 74,5\% - 99\%. Variasi ini disebabkan adanya perbedaan protokol perawatan, kriteria inklusi gigi yang dirawat, waktu kontrol, serta definisi yang berbeda-beda dari kesuksesan secara klinis, radiografis atau keduanya..$^{5,6,8}$

Pada laporan kasus ini akan dibahas kegagalan perawatan saluran akar dengan bahan pengisi kombinasi ZOE-formokresol pada gigi sulung dengan abses dentoalveolar.

\section{LAPORAN KASUS}

\section{Kunjungan pertama}

Anak laki-laki usia 4 tahun datang ke klinik IKGA FKG UI karena dirujuk dari Puskesmas Setiabudi dengan diagnosis sementara 74 gangren pulpa dan abses. Pasien mengeluhkan gigi bawah kiri belakang berlubang besar dan sakit sejak 1 bulan yang lalu serta pernah bengkak beberapa kali. Bengkak telah terjadi sejak 1 minggu yang lalu. Pasien diberikan antibiotik dan antipiretik dari puskesmas. Saat datang antibiotik sudah habis diminum. Pasien sudah beberapa kali ke puskesmas untuk perawatan gigi tersebut.

Dari pemeriksaan ekstraoral tidak ada asimetri wajah pada regio kiri bawah. Kelenjar getah bening kanan dan kiri teraba, lunak dan tidak sakit. Dari pemeriksaam intraoral didapatkan edema dan fistula pada regio 74 . Status kebersihan mulut buruk dengan indeks plak 2. Dilakukan pemeriksaan radiografis pada regio 74 dan 75 (Gambar 1).

Diagnosis keluhan utama regio 74 dentoalveolar abses kronis (DAAK) ec 74 KMP (karies mencapai pulpa) non vital. Gigi 75 pasca perawatan endodontik di dokter gigi lain, dilihat dari pemeriksaaan radiografisnya. Terdapat karies pada beberapa gigi lain. Sikap anak selama pemeriksaan berani. Rencana perawatan pada pasien ini meliputi dental health education (DHE) dan profilaksis oral; 74 PSA dengan restorasi MC (metal crown); $75 \mathrm{MC}$; gigi-gigi lain dirawat sesuai indikasinya.

Pada kunjungan ini, dilakukan DHE, profilaksis oral, dan perawatan saluran akar (PSA) 74. Prosedur berupa pembukaan kamar pulpa, ekstirpasi, irigasi, preparasi saluran akar, medikasi intrakanal, dan penutupan sementara dilakukan.

\section{Kunjungan kedua}

Dilakukan satu minggu setelah kunjungan pertama. Pada pemeriksaan klinis terlihat regio 74 hiperemi,

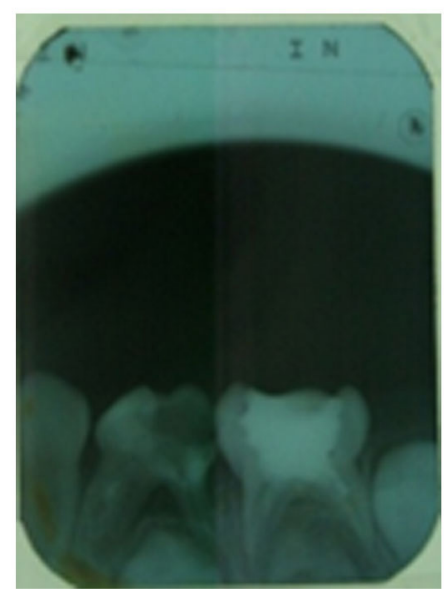

Gambar 1. Gambaran radiograf saat pasien datang. Pada regio 74 terdapat radiolusensi pada mahkota gigi bagian oklusal dan distal mencapai pulpa, terdapat radiolusensi pada daerah periradikular dan sekitar furkasi, resorpsi akar mencapai sepertiga apikal pada akar mesial dan distal, terdapat gambaran radiopak pada sepertiga tengah saluran akar mesial, serta tampak benih gigi 34. Pada regio 75 tampak gambaran radiopak pada kamar pulpa, tidak ada kelainan periradikular, tidak ada lesi di daerah furkasi, belum terjadi resorpsi akar dan terdapat benih gigi 35 .

edema, perkusi dan palpasi positif. Pada kunjungan ini dilakukan irigasi, preparasi saluran akar dan medikasi dengan formokresol. Pengisian saluran akar akan dilakukan 10 hari selanjutnya.

\section{Kunjungan ketiga}

Dilakukan 10 hari setelah kunjungan sebelumnya. Pada kunjugan ini tidak terdapat keluhan subjektif pada gigi 74. Keadaan gingiva sekitar 74 terlihat normal, dengan pemeriksaan perkusi dan palpasi negatif. Dilakukan pengisian gigi 74 dengan ZOE dan basis semen fosfat. Dilakukan pemeriksaan radiografis untuk melihat kualitas pengisian. (Gambar 2)

\section{Kunjungan keempat}

Evaluasi dilakukan 1 minggu sesudah pengisian saluran akar dilakukan. Pada evaluasi pemeriksaan tidak terdapat keluhan subjektif, perkusi dan palpasi gigi 74 tidak peka, namun terlihat ada fistula di regio 75. Pada kunjungan ini diagnosis DAAK pada 75 dibuat dan dilakukan PSA ulang pada gigi 75.

\section{Kunjungan kelima}

Evaluasi ini dilakukan 20 hari setelah PSA gigi 74, pada kunjungan ini terlihat keadaan gigi 75 normal, namun terdapat fistula pada gigi 74 . Dilakukan perawatan ulang pada gigi 74, dengan rencana pengisian 1 minggu yang akan datang.

\section{Kujungan keenam}

Tidak ada keluhan subjektif dan pemeriksaan objektif normal. Pada kunjungan ini dilakukan pengisian dengan ZOE yang dikombinasi dengan formokresol untuk meningkatkan sifat antibakteri bahan pengisi. 


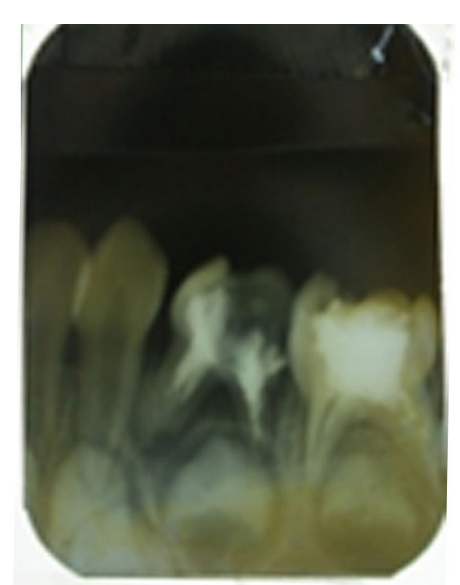

Gambar 2. Pengisian dengan ZOE telah dilakukan pada gigi 74

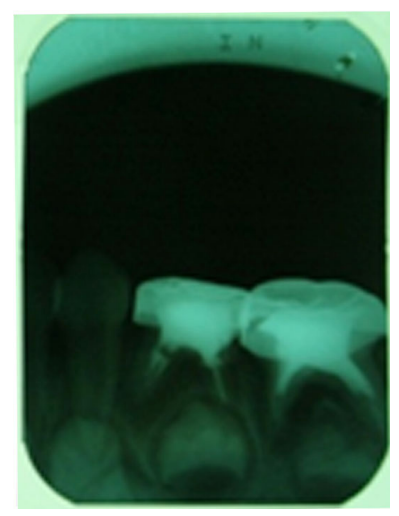

Gambar 3. Evaluasi setelah pemasangan mahkota logam pada gigi 74 dan 75

\section{Kunjungan ketujuh}

Evaluasi setelah 1 minggu terlihat tidak adanya keluhan subjektif pada gigi 74, maka dilakukan pengisian dengan pasta ZOE, dan dilakukan kontrol pada gigi 74 dengan hasil keluhan subjektif, palpasi dan perkusi negatif. Evaluasi dijadwalkan 1 minggu dengan rencana pembuatan mahkota logam.

\section{Kunjungan kedelapan}

Evaluasi paska pengisian baik maka dilakukan preparasi dan pemasangan mahkota logam pada gigi 74 dan 75. Pemeriksaan radiografis dilakukan dua minggu sesudah pemasangan untuk mengevaluasi hasil pemasangan mahkota logam. (Gambar 3)

\section{Kunjungan kesembilan}

Tiga bulan setelah pemasangan mahkota logam dilakukan evaluasi. Pada kunjungan ini tidak ada keluhan subjektif, palpasi, perkusi negatif, serta gingiva normal. Dilakukan juga foto radiograf untuk mengevaluasi kondisi periradikular 74. (Gambar 4)

\section{Kunjungan kesepuluh}

Pada kontrol 74 dan 75 pada tanggal 14 September 2013, pasien mengeluhkan gigi terasa sakit jika

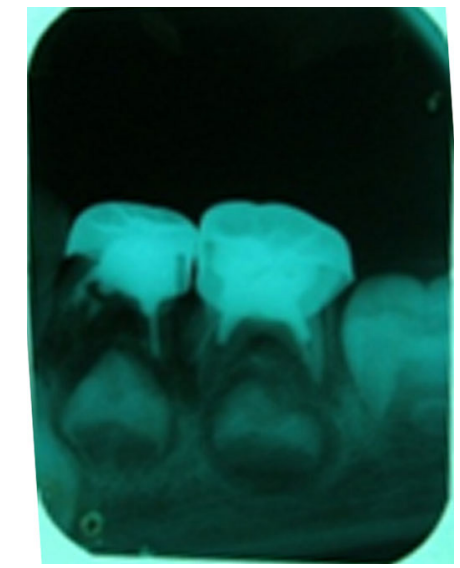

Gambar 4. Kontrol 3 bulan Setelah Pemasangan MC. Dari hasil radiograf didapatkan mulai tampak pembentukan tulang alveolar di daerah periradikular, resorpsi akar terjadi pada $1 / 3$ apikal akar dan pembentukan benih gigi 34 mencapai $1 / 3$ servikal mahkota.

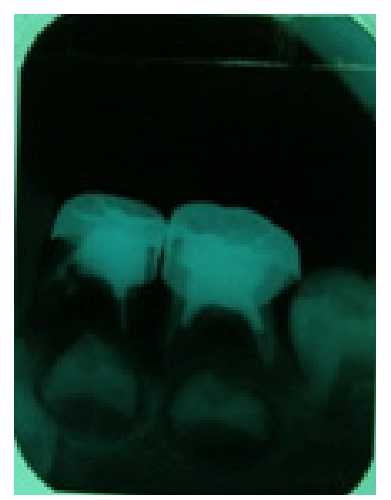

Gambar 5. Kondisi klinis dan radiograf 7 bulan setelah perawatan. Terlihat gambaran radiolusen yang luas pada periradikular gigi 74 .

dipakai mengunyah. Dari pemeriksaan klinis gingiva kemerahan dan terdapat fistula pada regio 74 , perkusi dan palpasi positif, 74 goyang derajat dua. Gingiva regio 75 tidak ada kelainan dan tidak ada kegoyangan gigi 75. Dilakukan pemeriksaan radiografik. Diputuskan untuk dilakukan ekstraksi pada gigi 74 karena terdapat gambaran radiolusen yang meluas. Pasien tidak kembali untuk melanjutkan perawatan. (Gambar 5).

\section{PEMBAHASAN}

Seorang anak laki-laki usia 4 tahun dirujuk dari puskesmas dengan diagnosis 74 gangren pulpa. Penegakan diagnosis keluhan utama di klinik Kedokteran Gigi Anak adalah regio 74 DAAK et causa 74 KMP non vital, yang ditentukan berdasarkan riwayat bengkak yang hilang timbul sejak 1 bulan yang lalu, pemeriksaan klinis adanya fistula dan edema pada regio 74, gigi 74 karies mencapai pulpa, serta pemeriksaan radiografis menunjukkan radiolusensi di bagian mahkota gigi mencapai pulpa, dan radiolusensi pada daerah periradikular. 
Pada kasus ini perawatan yang dipilih adalah PSA dan restorasi $\mathrm{MC}$, sesuai dengan indikasinya yaitu gigi mengalami infeksi irreversible, resorpsi akar minimal, masih tampak gambaran saluran akar pada radiograf, dan sisa jaringan gigi masih dapat direstorasi. Diharapkan terjadi penyembuhan pada regio 74 dan gigi dapat dipertahankan sampai waktu eksfoliasinya. Keuntungan dilakukannya PSA adalah menjaga fungsi mastikasi, mempertahankan ruang untuk gigi tetap, mencegah munculnya masalah dalam berbicara, mencegah kebiasaan buruk lidah, mempertahankan fungsi estetik, mencegah efek psikologis dari kehilangan gigi, dan mencegah gangguan erupsi gigi tetap. Kehilangan dini gigi sulung bisa menyebabkan semakin cepat atau terlambatnya erupsi gigi tetap, tergantung tahap perkembangannya. ${ }^{8,9}$

Tantangan melakukan PSA pada kasus ini adalah kondisi patologis yang cukup luas serta telah dilakukan perawatan endodontik pada gigi 74 berdasarkan anamnesa pasien dan gambaran radiopak pada $1 / 3$ tengah saluran akar mesial yang kemungkinan adalah sisa bahan pengisi saluran akar. Tantangan lain dalam melakukan PSA pada gigi molar sulung disebabkan oleh kurangnya konsistensi protokol perawatan dan medikamen berdasarkan evidence-based dan sulitnya proses cleaning and shaping saluran akar gigi molar sulung yang kompleks. Perawatan endodontik gigi sulung bergantung pada penggunaan agen kimia dan penggunaan bahan pengisi yang bersifat antimikroba, daripada debridement secara mekanis., ${ }^{5,6,8}$

Prosedur PSA meliputi preparasi secara mekanis, irigasi saluran akar, medikasi intrakanal, dan pengisian dengan material antimikroba. Pada kasus ini awalnya digunakan ZOE sebagai bahan pengisi saluran akar, namun 3 minggu kemudian terdapat fistula di regio 74. Dilakukan PSA ulang dengan preparasi mekanis seoptimal mungkin untuk mencegah perforasi dan terdorongnya bahan pengisi ke periapikal. Hal ini dilakukan karena dari foto radiograf tampak dinding saluran akar sudah tipis. Selanjutnya pengisian dengan kombinasi ZOE-formokresol untuk meningkatkan efek antibakteri. Penambahan formokresol diharapkan dapat meningkatkan kesuksesan perawatan dan mempercepat resorbsi bahan pengisi. Formokresol pada konsentrasi 0,33-0,5\% bersifat bakterisida terdahap Streptococcus faecelis, Streptococcus salivarius, dan Staphylococcus aureus. Pada penelitian mengenai keefektifan sifat antibakteri lima bahan pengisi saluran akar, didapatkan kombinasi ZOE-formokresol memiliki zona inhibisi paling luas. Aksi antimikroba didapatkan dari kandungan formaldehid pada formokresol, sedangkan kresol adalah pelarut formaldehid, dan merupakan desinfektan. Tingkat keberhasilan ZOE sebagai bahan pengisi menurut suatu penelitian adalah $82,5 \%$, sedangkan pada penelitian lain perawatan saluran akar dengan bahan pengisi kombinasi ZOE-formokresol didapatkan tingkat keberhasilan klinis yang lebih tinggi yaitu $90 \%$, dan secara radiografis $77,3 \%$. $, 6,8,10,11$
Gigi paska PSA harus dikontrol secara periodik dengan pemeriksaan klinis maupun radiografis yang dilakukan setiap 6 bulan, atau lebih sering pada pasien dengan infeksi gigi akut. ${ }^{9}, 12$ Pada kasus ini dilakukan kontrol periodik 1, 3 dan 7 bulan. Pada kontrol 1 dan 3 bulan didapatkan kondisi klinis yang baik pada regio 74 , namun secara radiografis belum tampak deposisi tulang yang signifikan.. Pada kontrol 7 bulan, pasien mengeluhkan gigi terasa sakit jika dipakai mengunyah. Dari pemeriksaan klinis didapatkan gingiva kemerahan dan fistula pada regio 74 , serta gigi 74 goyang derajat dua. Pemeriksaan radiografis menunjukkan area radiolusen yang luas pada periradikular 74 . Kemungkinan kegagalan PSA pada kasus ini dapat disebabkan oleh kompleksnya anatomi gigi sulung, pemilihan bahan pengisi, peletakan bahan pengisi saluran akar yang kurang adekuat, atau kondisi patologis yang sudah meluas.

Menurut anatomi gigi sulung secara umum, jumlah saluran akar gigi molar sulung mandibula adalah 2-4 dengan pola morfologi mengikuti bentuk eksternal akar. Pada penelitan banyak ditemukan variasi karena karena saluran akar pada gigi sulung memiliki banyak ramifikasi dan delta. Gigi molar sulung mandibula pertama dikatakan memiliki banyak variasi karena akar yang lebih tebal. Kompleksitas anatomi saluran akar ini menimbulkan kesulitan secara klinis. Hal ini menyebabkan pentingnya pemilihan teknik dan material untuk PSA gigi sulung karena preparasi mekanis secara menyeluruh sulit dilakukan. ${ }^{6,8,9}$

Pengisian saluran akar pada kasus ini dilakukan menggunakan plugger pada saluran akar lalu dilakukan penekanan dengan cotton pellet. ${ }^{2}$ Pada kasus ini tampak gambaran radiolusen di bagian servikal saluran akar mesial di foto setelah pengisian dengan ZOE-formokresol. Hal ini menunjukkan peletakan bahan pengisi yang kurang adekuat dan bisa menyebabkan kurangnya seal pada saluran akar sehingga memungkinkan terjadinya kegagalan perawatan.

Bahan pengisi ZOE-formokresol memiliki kekurangan karena kandungan formokresolnya. Kandungan formaldehid pada formokresol dinyatakan toksik, merusak jaringan ikat, serta dapat diabsorbsi secara sistemik. Penambahan bahan yang mengandung formaldehid dinyatakan meningkatkan toksisitas eugenol serta menghambat terjadinya penyembuhan. Dahulu bahan yang mengandung formaldehid sering digunakan karena menyebabkan nekrosis jaringan termasuk sel saraf terminal dan sel imun sehingga membuat tanda-tanda inflamasi tertutupi. ${ }^{9}$ Pada beberapa penelitian dikatakan bahwa penambahan formokresol pada bahan pengisi ZOE tidak meningkatkan kesuksesan perawatan. ${ }^{6,10}$ Pada penelitian bikompatibilitas ZOE-formokresol dengan perbandingan $6 \mathrm{~g}: 1 \mathrm{ml}: 1 \mathrm{ml}$ didapatkan kematian sel, sitotoksik, dan menyebabkan sensitisasi imun. ${ }^{11,13,14}$ Pada kasus ini digunakan kombinasi ZOE- 
formokresol karena sifat antibakteri yang kuat dan tingkat keberhasilan yang mencapai $90 \%{ }^{5,6,8,10,11}$

Pada kasus ini dilakukan restorasi MC. Salah satu indikasi restorasi $\mathrm{MC}$ adalah gigi sulung paska PSA. MC memiliki tingkat keberhasilan yang tinggi, kuat, tahan lama, terjangkau, tekniknya tidak sensitif, dan dapat menutup gigi secara keseluruhan, tetapi beberapa kegagalan terjadi karena lepasnya mahkota atau margin yang kurang baik. Meskipun sudah dilakukan preparasi dengan hati-hati, margin gingiva MC seringkali tidak beradaptasi dengan sempurna. Adaptasi margin yang buruk dapat menyebabkan microleakage dan bakteri masuk ke struktur gigi, sehingga terjadi re-infeksi saluran akar yang sudah dirawat. Kemampuan semen untuk melapisi margin metal crown adalah faktor yang penting untuk mencegah kegagalan perawatan. Pada kasus ini digunakan Glass Ionomer Cement (GIC) tipe 1 untuk sementasi MC..$^{5,6,8,10,11}$ GIC menunjukkan adaptasi terhadap struktur gigi yang lebih baik daripada material lain, serta menurut penelitian hanya 5\% sampel dengan semen GIC yang mengalami leakage. ${ }^{12,15-17}$

Berdasarkan rekomendasi AAPD, target dari perawatan saluran akar gigi sulung adalah gejala klinis harus hilang dalam beberapa minggu dan secara radiografis proses infeksi harus dapat teratasi dalam waktu 6 bulan, yaitu dengan terbentuknya deposisi tulang pada area yang tadinya radiolusen. Ketika proses infeksi tidak bisa dihentikan dengan perawatan pulpa yang sudah dilakukan, penyembuhan tulang pendukung tidak didapatkan, atau terjadi resorpsi patologis yang luas, dipertimbangkan dilakukan ekstraksi. ${ }^{2,12}$

Setelah ekstraksi dilakukan pengamatan pada gigi 74 . Tampak gambaran resorpsi akar yang tidak beraturan pada daerah furkasi sampai terlihat saluran akar. Resorpsi pada gigi sulung terjadi secara fisilologis atau patologis. Resorpsi patologis yang seringkali disebabkan oleh nekrosis pulpa dapat terbagi menjadi dua, yaitu resorpsi internal dan eksternal. Nekrosis pulpa mengaktifkan produksi sitokin sehingga menyebabkan apoptosis odontoblas dan fibroblas disekitar apeks gigi. Selain itu, infeksi pulpa menstimulasi peningkatan aktivitas osteoklas sehingga menginisiasi terjadinya resorpsi. Resorbsi patologis gigi terjadi secara tidak beraturan disekitar apeks gigi. ${ }^{18}$

\section{DAFTAR PUSTAKA}

1. Dean JA, Avery DR, McDonald RE. McDonald and Avery's Dentistry for the child and adolescent. 8th ed. Mosby. 2004.

2. Pinkham JR, Casamassimo PS, Fields HW, McTigue DJ, Novak A. Pediatric Dentistry Infancy Through Adolescence. 4th ed. St Louis: Elsevier Saunders. 2005.
3. Torabinejad M, Fouad A. Principles and Practice of Endodontics. Philadelphia: WB Saunders. 2002.

4. Costa LR, Daher A, Queiroz M. Early childhood caries and body mass index in young children from low income families. Int J Environ Res Public Health. 2013;10: 867-78.

5. Prathima GS, Sudha P. An in vitro inhibition of bacteria from mixed culture by five root canal materials. IJCD. 2011;2:54-60. Availble from: http:// edentj.com/index.php/ijcd/article/viewFile/624/328

6. Jha M, Patil SD, Sevekar S, Jogani V, Shingare P. Pediatric obturating materials and technique. $\mathrm{J}$ Contem Dent. 2011; 1:27-32.

7. Barja-Fidalgo F, Riberio MM, Oliveira MAA, de Oliveira BH. A Systematic review of root canal filling material for deciduous teeth: is there an alternative for ZOE?. ISRN Dentistry. 2011:1-7

8. Stallaert, Karen M. A retrospective study of root canal therapy in non vital primary molars. University of Toronto. 2011.

9. Cohen Stephen, Hargreaves KM. Pathways of the Pulp. 8th ed.St Louis: Mosby Co. 2002.

10. Praveen P, Anantharaj A, Venkataragahavan K, Prathibha RS. A review of obturating materials for primary teeth. SRM University J Dent Sci. 2011;1.

11. Chen CW, Kao CT, Huang TH. Comparison of the biocompatibility between two endodontic filling materials for primary teeth. Chin Dent J. 2005;24:28-43.

12. American Academy of Pediatric Dentistry. Guideline on Pediatric Restorative Dentistry. 2012. Available from: http://www.aapd.org/media/ Policies_Guidelines/G Restorative.pdf.

13. Bains $\bar{M}$, Li X, Malik IA, Pereira M, Tewary P. Success of formocresol versus other medicaments used in vital pulpotomy in children with primary teeth. University of Toronto. 2009. Available from: http://www.dentistry.utoronto.ca/system/files/ group4report2009.pdf.

14. Cheong C, Wong G, Law MKT, King NM. Is formocresol still safe for use in pediatric dentistry? Part I. Dental Asia. 2008; July/August: 19-22. Available from: http://pulpotec.com/PDF/Prof $\% 20$ King\%202008.pdf.

15. Berg JH, Pettet DE, Hutchins MO. Microleakage of three luting agents used with stainless steel crowns. Pediatr Dent. 1988;10:195-8.

16. Shiflett K, White SN. Microleakage of cements for stainless steel crowns. Am Acad Pediatr Dent. 1997;19:262-6.

17. Mirkarimi M, Bargrizan M, Estiri M. The microleakage of polycarboxylate, glass ionomer, and zinc phosphate cements for stainless steel crowns of pulpotomized primary molars. ZJMRS. 2013;15:6-9.

18. Fuss Z, Tsesis I, Lin S. Root resorption--diagnosis, classification and treatment choices based on stimulation factors. Dent Traumatol. 2003;19:17582. 